\title{
ABOVEGROUND PRODUCTIVITY AND FLORISTIC STRUCTURE OF A HIGH SUBALPINE HERBACEOUS MEADOW
}

\author{
Douglas C. Andersen,* Robert S. Hoffmann, †and Kenneth B. Armitage
}

\begin{abstract}
The aboveground primary productivity within each of four areas, differing in length of the snow-free season, was determined in a high subalpine $(3380 \mathrm{~m})$ herbaceous meadow in Colorado. Net productivity, minus losses to herbivores, ranged from $114 \mathrm{~g} \cdot \mathrm{m}^{-2} \cdot \mathrm{yr}^{-1}$ in the area with the shortest snow-free period, to maximum values of $192 \mathrm{~g} \cdot \mathrm{m}^{-2} \cdot \mathrm{yr}^{-1}$ in areas with snow-free periods of intermediate length. Caltha leptosepala and Senecio crassulus, the only dominant forb species com-

mon to all four areas, showed differing patterns of productivity within and between areas. Domestic sheep may have removed up to $38 \%$ of the peak standing crop within the study area during $6 \mathrm{~h}$ of grazing. Variation in dominance-diversity curves among the four areas suggests that the effect of snow cover in controlling the length of the growing season may be less important than its influence on moisture availability in determining the overall structure of this subalpine community.
\end{abstract}

\section{INTRODUCTION}

The pattern of snowmelt and the presence of late-lying snowbanks influence the composition and productivity of subalpine and alpine plant communities (Billings and Bliss, 1959; Holway and Ward, 1963; Bliss, 1969; Kuramoto and Bliss, 1970; Canaday and Fonda, 1974; Webber, 1974). The varied ability of species to withstand drought, which affects both early and late-opening areas, and short growing seasons promote compositional differences within relatively small areas. Community productivity seems most strongly affected by soil moisture availability and the length of the growing season (Billings and Bliss, 1959; Webber, 1974).

\footnotetext{
*Department of Biology and Ecology Center, Utah State University, Logan, Utah 84322.

$\dagger$ Museum of Natural History and Department of Systematics and Ecology, The University of Kansas, Lawrence, Kansas 66045.

¥Division of Biological Sciences, The University of Kansas, Lawrence, Kansas 66045.

0004-0851/79/040467-10\$01.50

(C) 1979, Regents of the University of Colorado
}

This paper presents data, collected during the 1974 growing season, which relate snowmelt patterns to both aboveground productivity and community structure in a high subalpine (i.e., lowest subzone of alpine; Barry and Ives, 1974) meadow community located in the Elk Mountain Range, Colorado. This type of community, which might be broadly characterized as a weakly developed "upland herb" community (Langenheim, 1962) with areas of snowflush and streamside species, has been neglected in productivity studies. In addition, this study presents the first examination of high subalpine plant community structure using production estimates as importance or dominance values, a method preferred by some workers (e.g., Whittaker, $1965,1975: 88$ ). Restriction to use of the term "dominance" will be made hereafter in order to avoid confusion arising from the established use of "importance value" to denote the synthetic variable dependent on values of relative dominance, frequency, and density (Curtis and McIntosh, 1951; McIntosh, 1958).

D. C. ANDERSEn ET AL. / 467 


\section{STUDY AREA}

North Pole Basin $\left(107^{\circ} \mathrm{W} 39^{\circ} \mathrm{N}\right)$, USGS Snowmass Mountain Quadrangle, Colorado, is a narrow $3-\mathrm{km}$ long hanging valley, oriented in a north-south direction. A continuous ridge ranging from 3680 to $4100 \mathrm{~m}$ rims the basin on three sides. The basin floor rises from $3250 \mathrm{~m}$ and continuous coniferous forest at its northern terminus, to alpine tundra at $\sim 3650 \mathrm{~m}$. The study area, encompassing $\sim 5$ ha, was approximately at the midpoint of the basin, at $3380 \mathrm{~m}$. Outcrops of limestone bedrock, which partially underlies the basin, appear in portions of the study area. The central portion of the study area has a well-developed soil, while the east and particularly the west sides feature exposed rock and less mature soils.

Heavy snow accumulations are common for the area. The lower portions of the basin generally retain snow well into July. Permanent snowfields occur in the higher portions of the basin. Fifty percent snowcover occurred in late June 1974, early July 1973 and 1976, and mid-July in 1975 (Johns, pers. comm., 1978; Johns and Armitage, 1979). Thus 1974 probably represents a year with a relatively long growing season.

During early phases of snowmelt, much of the central portion of the study area is saturated with meltwater. An ephemeral stream carried runoff through the study area until mid-August in 1974, after which runoff disappeared into the stream channel above the study site, and reappeared as a spring just below it.

Air temperatures recorded at the western edge of the study site rarely rose above $18^{\circ} \mathrm{C}$ during the day. Cold air drainage plus the short daily interval during which the basin floor receives direct solar radiation produce typical nighttime temperatures of 3 to $5^{\circ} \mathrm{C}$. During the latter half of the summer, afternoon cloudiness and brief thundershowers were common. Snow fell for the first time in early September; the first of the 1974/75 snowpack was probably established in early October.

No effort was made to prevent use by or assess the impact of consumers native to the study area. Marmots (Marmota flaviventris) were relatively abundant (Andersen et al., 1976), and deermice (Peromyscus maniculatus), voles (Microtus montanus), chipmunks (Tamias [ = Eutamias] minimus), and pocket gophers (Thomomys talpoides) were resident within the study area. The biomass removed by these rodents may have been considerable, and thus the productivity estimates presented should be considered minimal. Other herbivores of less importance included porcupine (Erethizon dorsatum), snowshoe hare (Lepus americanus), and mule deer (Odocoileus hemionus). The relative impact of invertebrate herbivores is unknown.

Although the early history of grazing by domestic livestock is unknown, the entire basin was subject to grazing by sheep for at least the 10 to $15 \mathrm{yr}$ prior to 1973 , when no grazing took place. A herd of approximately 1100 (estimated from photographs) sheep unexpectedly entered North Pole Basin in midAugust, and grazed the study area for less than $6 \mathrm{~h}$ on 22 August 1974. Standing crop data indicate that most areas had reached peak biomass by that time, although individual plant species may not have (see Results).

\section{METHODS}

The pattern of snowmelt on the study area was recorded by photographing the area at approximately weekly intervals from the adjacent mountainside. On the basis of the photographs, contours were drawn on a detailed map of the area, outlining snowcovered areas. Four "snow zones" defined by these contours (Figure 1) were analyzed, covering the period from nearly continuous snow cover in midMay to complete snowmelt in late July. Inclusive dates covered in each snow zone are given in Figure 1.
Herbaceous vegetation was sampled by means of permanent $0.5 \times 2.0 \mathrm{~m}$ quadrats within which species were identified and phenological condition noted, and nested $50 \times 25 \mathrm{~cm}$ quadrats (Wiegert, 1962) within which forbs (Dicotyledoneae) were clipped by species, and graminoids (Monocotyledoneae) clipped by family. The permanent quadrats were located randomly with respect to both snowmelt contours and floristic associations. Some effort was made to insure uniform sampling effort in all portions of the study area, 


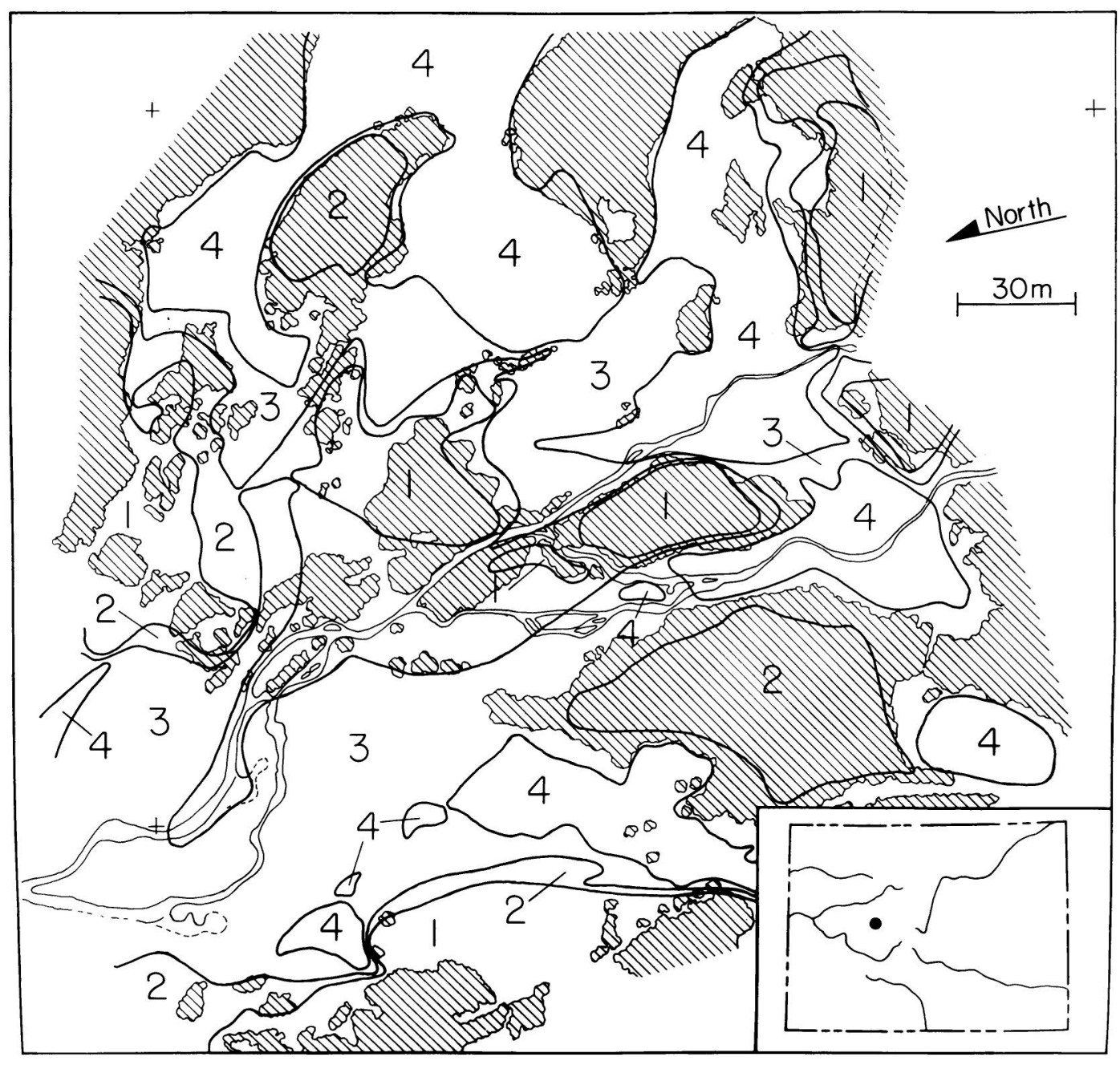

FIGURE 1. North Pole Basin, Colorado, showing contours delineating the four snow zones in which vegetation was analyzed. Hatched areas are stands of tall willow (Salix sp.) and krummholz. The ephemeral stream flowing north through the center of the study area is outlined. Most of snow zone 3 adjacent to the streambed has little slope, while the eastern and western portions of the study area rise steeply. The periods during which the snow zones became snow free were as follows: 1 - prior to 29 May (18 May used as mean emergence date); 2-29 May to 11 June (5 June); $3-12$ to 23 June (17 June); $4-$ after 23 June (29 June). Most snow in the study area had melted by early July, although some remained until late July.

except that areas of tall willow (Salix sp.) and krummholz (Figure 1) were not examined. The first quadrats were established 18 June, with additional localities established as snowmelt proceeded. A different $0.125-\mathrm{m}^{2}$ area (selected randomly) was clipped at each site during each sampling period. Samples were immediately air-dried in paper bags and later oven-dried $\left(60^{\circ} \mathrm{C}\right)$ for at least $5 \mathrm{~d}$ prior to weighing.
The number of quadrats upon which standing crop estimates are based varied between both sampling periods and snow zones (Table 1). Several quadrats located in the first areas to become snow-free were not monitored after mid-July, in order to increase effort in areas becoming snow free during June and July. Because the markers used to identify quadrat locations appeared to attract the sheep when they entered the study area, 
all quadrats were relocated (again randomly) following their departure.

Several exclosures, erected early in the growing season with the intention of assessing the impact of marmots on the vegetation, were used instead to assess the impact of the unanticipated grazing by sheep. Half of three exclosures, each $1 \mathrm{~m}^{2}$, were clipped just prior to the arrival of the sheep, and the sheep then allowed to graze both halves. Two of the areas were revisited after departure of the sheep, and the previously uncut halves were clipped.

All aboveground portions of the plants con- sidered in the study die at the end of the growing season. Also, previous year's growth cannot be confused with the current year's standing dead, since all dead herbaceous vegetation is crushed by the winter snowpack. Thus, the maximum standing crops recorded represent minimal estimates of annual net aboveground productivity. While no attempt was made to account for vegetation death and disappearance between sampling periods (Bradbury and Hofstra, 1976), this source of error in production estimates is probably inconsequential.

\section{RESULTS}

The heterogeneous nature of the herbaceous vegetation within the study area was confirmed by the results of cluster analysis performed on presence-absence data for all species noted within the $1-\mathrm{m}^{2}$ quadrats (NTSYS Packaged Programs, University of
Kansas Computer Center, 1974; Sokal and Sneath, 1963: 185). No easily delimited major groupings were formed; those quadrats forming the numerous small clusters were spatially intermixed. These results indicate that the vegetation forms a mosaic of floral assem-

TABLE 1

Sample periods and sample sizes for quadrats clipped in North Pole Basin, $1974^{\mathrm{a}}$

\begin{tabular}{ccccccc}
\hline & Period during which & Mean date used in & \multicolumn{3}{c}{ Sample sizes in snow zone } \\
\cline { 4 - 6 } Cutting & sampling occurred & standing crop analyses & 1 & 2 & 3 & 4 \\
\hline 1 & 18 June-12 July & 1 July & 21 & 14 & 31 & 11 \\
2 & 9 July-1 August & 20 July & 20 & 14 & 30 & 19 \\
3 & 30 July-15 August & 9 August & 11 & 14 & 28 & 24 \\
4 & 25 August-9 September & 2 September & & 13 & 41 & 39 \\
5 & 18 September-30 September & 22 September & & 13 & 39 & 38 \\
\hline
\end{tabular}

${ }^{a}$ The snowmelt periods corresponding to the four snow zones are shown in Figure 1.

TABLE 2

Net aboveground productivity $\left(g \cdot m^{-2} \cdot y r^{-1}\right)$ within four snow zones ${ }^{\mathrm{a}}$

\begin{tabular}{|c|c|c|c|c|}
\hline \multirow[b]{2}{*}{ Vegetation component } & \multicolumn{4}{|c|}{ Snow zone } \\
\hline & 1 & 2 & 3 & 4 \\
\hline Herbs & 116.8 & 127.2 & 117.6 & 65.6 \\
\hline Grasses $\left(\right.$ Poaceae) ${ }^{\mathrm{b}}$ & 38.4 & 53.6 & 36.0 & 19.2 \\
\hline Sedges (Cyperaceae) ${ }^{c}$ & 12.0 & 10.4 & 19.2 & 23.2 \\
\hline Rushes (Juncaceae) & 2.4 & 0.8 & 4.0 & 6.4 \\
\hline Total & 169.6 & 192.0 & 176.8 & 114.4 \\
\hline
\end{tabular}

${ }^{\text {aD }}$ ates when snow zones became snow free are given in Figure 1 legend.

bIncludes Agropyron sp., Bromus marginatus, Deschampsia caespitosa, Phleum alpinum, Poa alpina, Poa sp., and Trisetum spicatum.

'Includes Carex ebenea. 
blages grading into one another at their boundaries. Only those relatively small areas free of snow in mid-May were easily established as separate associations. These areas contributed little to the productivity of the area as a whole. Thus, community productivity is presented by snow zones, and no attempt is made to assess productivity by plant association.
The four snow zones varied in net productivity from $192 \mathrm{~g} \cdot \mathrm{m}^{-2} \cdot \mathrm{yr}^{-1}$ to $114 \mathrm{~g} \cdot \mathrm{m}^{-2} \cdot \mathrm{yr}^{-1}$ (Table 2). Graminoids produced about $1 / 3$ of the total production in all but snow zone 4 , where they contributed $43 \%$. Graminoid productivity was dominated by sedges in snow zone 4 ; in all other cases grasses predominated.

Marsh marigold (Caltha leptosepala) and

TABLE 3

Productivity $\left(\mathrm{g} \cdot \mathrm{m}^{-2} \cdot \mathrm{yr}^{-1}\right)$ of forbs contributing at least $1 \%$ to the aboveground productivity within any of the four snow zones ${ }^{\mathrm{a}}$

\begin{tabular}{|c|c|c|c|c|}
\hline \multirow[b]{2}{*}{ Species } & \multicolumn{4}{|c|}{ Snow zone } \\
\hline & 1 & 2 & 3 & 4 \\
\hline Caltha leptosepala & $11.95^{* *}$ & $15.90^{* *}$ & $23.26^{* *}$ & $24.96 * *$ \\
\hline Senecio crassulus & $5.73^{*}$ & $11.06^{* *}$ & $10.02 * *$ & $3.75^{* *}$ \\
\hline Lupinus argenteus & $7.47 * *$ & $7.47 * *$ & $10.57 * *$ & 0.30 \\
\hline Geum rossii & & $4.84^{*}$ & $10.94 * *$ & $9.99 * *$ \\
\hline Delphinium barbeyi & & $20.17^{* *}$ & $12.35^{* *}$ & \\
\hline Ligusticum porteri & $11.32^{* *}$ & $5.99 *$ & $2.45^{*}$ & $1.07 *$ \\
\hline Helenium hoopesii & $14.24^{* *}$ & $4.76^{*}$ & $1.22^{*}$ & \\
\hline Anemone narcissiflora & & $1.42^{*}$ & $3.95^{*}$ & $5.66^{* *}$ \\
\hline Sedum rosea & $8.65^{* *}$ & 0.39 & & 0.36 \\
\hline Valeriana edulis & & $15.94^{* *}$ & 1.03 & \\
\hline Helianthella quinquenervis & $6.51^{* *}$ & & & \\
\hline Thalictrum fendleri & $9.06^{* *}$ & 0.03 & & \\
\hline Cirsium scopulorum & $4.14^{*}$ & $4.53^{*}$ & $3.05^{*}$ & $0.95^{*}$ \\
\hline Mertensia ciliata & $1.85^{*}$ & $2.56^{*}$ & $3.96^{*}$ & $1.06^{*}$ \\
\hline Castilleja rhexifolia & $3.52^{*}$ & 0.02 & $1.78^{*}$ & $0.89^{*}$ \\
\hline Veronica wormskjoldii & 0.53 & $2.06^{*}$ & $2.99 *$ & $2.28^{*}$ \\
\hline Oxypolis fendleri & $1.48^{*}$ & $1.86^{*}$ & $1.65^{*}$ & 0.38 \\
\hline Geranium richardsonii & $5.80^{*}$ & $3.66^{*}$ & $5.45^{*}$ & 0.07 \\
\hline Castilleja septentrionalis & $2.16^{*}$ & $3.91^{*}$ & 0.74 & 0.46 \\
\hline Potentilla concinna & $2.74^{*}$ & $2.10^{*}$ & 0.27 & 0.10 \\
\hline Epilobium angustifolium & 0.42 & $2.01^{*}$ & & $0.96^{*}$ \\
\hline Arnica mollis & & 0.33 & $1.42^{*}$ & $1.01^{*}$ \\
\hline Bistorta bistortoides & & 1.24 & $1.35^{*}$ & $0.96^{*}$ \\
\hline Sibbaldia procumbens & & 0.58 & $1.58^{*}$ & $1.92^{*}$ \\
\hline Potentilla gracilis & $3.56^{*}$ & $1.34^{*}$ & 0.13 & \\
\hline Stellaria umbellata & $1.29 *$ & 1.14 & 0.24 & 0.23 \\
\hline Potentilla diversifolia & $3.66^{*}$ & 0.57 & 0.35 & 0.24 \\
\hline Aquilegia caerulea & $1.50^{*}$ & 0.27 & 0.13 & \\
\hline Erythronium grandiflorum & & 1.26 & $1.20^{*}$ & \\
\hline Thlaspialpestre & 0.30 & 0.56 & 0.66 & $0.62^{*}$ \\
\hline Trifolium sp. & 0.71 & 0.50 & 0.85 & $0.81^{*}$ \\
\hline Primula parryi & & & 0.06 & $1.12^{*}$ \\
\hline Achillea millefolium & $1.60^{*}$ & 0.22 & & \\
\hline $\begin{array}{l}\text { Percentage of total forb } \\
\text { productivity represented }\end{array}$ & 94.3 & 93.3 & 88.1 & 92.0 \\
\hline
\end{tabular}

a** Indicates a contribution of $5 \%$ or more; * indicates a contribution of at least $1 \%$.

D. C. ANDERSEN ET AL. / 471 
butterweed (Senecio crassulus) were the only species contributing more than $4 \%$ to the productivity of forbs in all four snow zones (Table 3). These two species were among 12 (Table 3) accounting for 64 to $72 \%$ of the forb productivity within any snow zone.

Differences in dominance among these 12 species are most pronounced when either snow zone 1 or 4 , the first and last to become snow free, respectively, is compared to the other areas. Thalictrum fendleri, Helianthella quinquenervis, and Sedum rosea were the major contributors to productivity within the earliest opening area, while they were minor contributors or absent in snow zones 2 , 3 , and 4. Geum rossii and Anemone narcissiflora contributed significantly to snow zones 2,3 , and 4 ; both were absent from 1 . By contrast, Lupinus argenteus and Helenium hoopesii contributed significantly to all areas except snow zone 4 , where the latter was absent and Lupinus a minor contributor.

Caltha leptosepala and Senecio crassulus were each examined in detail for patterns in their productivity within and between snow zones. The mosaic nature of the meadow community leads to large variation in the species-specific biomass among quadrats. Even for these most dominant species, our largest sample sizes were often insufficient to reduce coefficients of variation to values less than $100 \%$. Thus, confidence intervals (Table 4) are large, and the following analyses should be considered as indicative of trends rather than definite patterns. Annual productivity (maximum standing crop) of
Caltha increased successively from snow zone 1 to snow zone 4 (Table 3 ). This same trend was evident in peak daily productivity, based on Table 4 and measured as the rate of change in standing crop between sampling periods. The length of time between snowmelt (mean emergence date, Figure 1 legend) and peak standing crop of Caltha was quite similar within each snow zone ( 45 to $55 \mathrm{~d}$ ).

Peak standing crops of Senecio were reached in progressively less time from snow zone 1 to snow zone 4. Also, maximum daily production rates were low in both early and late opening areas, as were peak standing crop values (Table 3 ).

The total standing crop of forbs within each of the snow zones except 4 peaked prior to the entry of sheep onto the study area. Individual species may not have peaked until later. Lupinus argenteus, for example, a dominant member of three snow zones, produced maximum standing crops at the fourth sampling, immediately following departure of the sheep, as did several less important species, including Erigeron coulteri and $E$. elatior.

The standing crop values recorded within the three exclosures prior to the sheep grazing (Table 5) were quite similar to the maximum values ( $=$ productivity) estimated for the individual snow zones (Table 2). While much variation is evident in the distribution of the biomass among the vegetational components, the total biomass within the plots is remarkably uniform.

A comparison of the mean biomass before

TABLE 4

Mean standing crops with $95 \%$ confidence intervals $\left(\mathrm{g} \mathrm{m}^{-2}\right)$ for Caltha leptosepala and Senecio crassulus within each snow zone at each sampling period ${ }^{a}$

\begin{tabular}{|c|c|c|c|c|c|c|c|}
\hline \multirow[b]{2}{*}{ Snow zone } & \multicolumn{7}{|c|}{ Sampling period } \\
\hline & 1 & 2 & & 3 & & 4 & 5 \\
\hline \multicolumn{8}{|c|}{ Caltha leptosepala } \\
\hline 1 & $11.95 \pm 17.22$ & $9.50 \pm$ & 13.70 & $9.92 \pm$ & 15.56 & & \\
\hline 2 & $1.34 \pm 2.61$ & $15.90 \pm$ & 26.44 & $12.42 \pm$ & 20.25 & 0.0 & 0.0 \\
\hline 3 & $10.82 \pm 6.03$ & $17.42 \pm$ & 9.16 & $23.26 \pm$ & 15.53 & $12.45 \pm 6.63$ & $2.34 \pm 2.26$ \\
\hline 4 & $19.88 \pm 26.33$ & $22.58 \pm$ & 12.14 & $24.96 \pm$ & 16.55 & $18.60 \pm 8.18$ & $7.32 \pm 4.01$ \\
\hline \multicolumn{8}{|c|}{ Senecio crassulus } \\
\hline 1 & $4.09 \pm$ & $5.44 \pm$ & 4.77 & $5.74 \pm$ & 6.20 & & \\
\hline 2 & $7.25 \pm$ & $10.72 \pm$ & 6.10 & $11.06 \pm$ & 8.60 & $9.21 \pm 6.05$ & $0.74 \pm 0.98$ \\
\hline 3 & $3.29 \pm$ & $10.02 \pm$ & 7.00 & $4.33 \pm$ & 3.79 & $3.55 \pm 1.58$ & $0.35 \pm 0.31$ \\
\hline 4 & $2.09 \pm$ & $3.75 \pm$ & 5.66 & $1.46 \pm$ & 1.49 & $1.90 \pm 1.31$ & $0.44 \pm 0.58$ \\
\hline
\end{tabular}

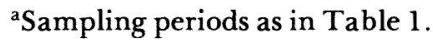

472 / ARCTIC AND ALPINE RESEARCH 
TABLE 5

Aboveground standing crops $\left(\mathrm{g} \mathrm{m}^{-2}\right)$ within exclosures before and after grazing by domestic sheep

\begin{tabular}{ccrr}
\hline \hline \multirow{4}{*}{ Plot $^{\mathrm{a}}$} & & \multicolumn{2}{c}{ Biomass } \\
\cline { 3 - 4 } & Vegetation & $\begin{array}{r}\text { Before } \\
\text { grazing }\end{array}$ & $\begin{array}{c}\text { After } \\
\text { grazing }\end{array}$ \\
\hline \multirow{4}{*}{1} & Herbs & 192.2 & 78.2 \\
& Grass & 11.6 & 5.4 \\
& Sedge & 6.2 & 16.8 \\
& Rush & 2.4 & 0.4 \\
& Total & 212.4 & 100.8 \\
& Herbs & 37.4 & 32.6 \\
2 & Grass & 143.4 & 100.8 \\
& Sedge & 16.2 & 21.8 \\
& Total & 197.0 & 145.2 \\
& Herbs & 93.6 & \\
& Grass & 96.8 & \\
& Sedge & 23.2 & \\
& Total & 213.6 & \\
& Mean & 207.7 & 128.0 \\
\hline
\end{tabular}

a Plots 1 and 2 were located in snow zone 3 , while plot 3 was in snow zone 2 ; plot 3 was not reclipped following grazing.

grazing, $208 \mathrm{~g} \mathrm{~m}^{-2}$, to that after grazing, 128 $\mathrm{g} \mathrm{m}^{-2}$, suggests that sheep removed $38 \%$ of the standing crop. This figure can be compared to the change in standing crops within snow zones 2,3 , and 4 between the third (immediately preceding grazing) and fourth (immediately following grazing) sampling periods. The clipped quadrats indicate a 16 to $37 \%$ reduction in the forb standing crop, and a 7 to $35 \%$ reduction in total herbaceous

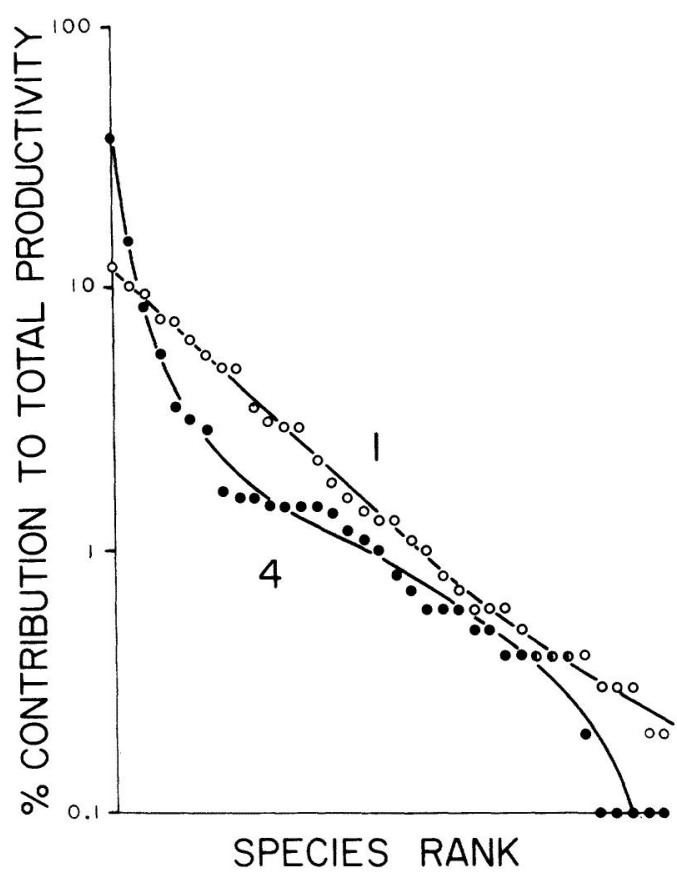

FIGURE 2. Dominance-diversity curves for forbs within snow zones 1 and 4 . Relative contributions of species to total forb productivity are plotted against species rank, with the largest contributor to the left on the abscissa.

standing crop. Thus, the $38 \%$ figure appears reasonable.

The dominant species of forbs within snow zones 1 and 4 are ranked in Figure 2 according to their relative contributions to total forb productivity within each of the snow zones. Rankings of species within snowzones 2 and 3 formed patterns intermediate to those shown in Figure 2.

\section{DISCUSSION}

The net aboveground productivity values obtained in this study are comparable to those reported for moist sites in the Colorado alpine tundra (Webber, 1974) and in subalpine "tall sedge" communities in the Olympic Mountains of Washington (Kuramoto and Bliss, 1970; Canaday and Fonda, 1974). Aboveground productivity in an alpine Deschamp. sia meadow in southeastern Wyoming
$(3240 \mathrm{~m})$, measured as the maximum aboveground standing crop at a single point in time, was intermediate to our two lowest values (Thilenius et al., 1974). Productivity at timberline sites, approaching $1000 \mathrm{~g} \cdot \mathrm{m}^{-2}$. $\mathrm{yr}^{-1}$ (Webber, 1974), may be greater than at sites above timberline. Belowground productivity, not considered in our estimates, could greatly influence total productivity. Assuming 
that belowground productivity in a high subalpine meadow community would be an amount equal to the aboveground productivity (Webber and May, 1977), 500 to 1000 $\mathrm{g} \cdot \mathrm{m}^{-2} \cdot \mathrm{yr}^{-1}$ appears a reasonable estimate of total annual productivity in our study area.

Plant productivity is generally considered suboptimal in early opening and late opening areas. In this study, the early opening area had aboveground productivity nearly equal to that of areas with moderate snow cover. The differences in the patterns of productivity of Senecio and Caltha probably reflect differing tolerances to conditions within the four snow zones. This interspecific variation is exemplified by the relatively low productivity of Senecio in snow zone 4 , where Caltha was most productive (Table 3 ). Phenological differences among alpine plant species, both between and within sites, can result from a variety of physical factors other than snow cover, including factors which affected the plant during the previous year (Wielgolaski, 1974). For example, the experimental addition of surface meltwater retarded phenology and lowered the vigor of some species relative to controls, presumably through the mixed effects of lowered soil temperature and increased soil moisture (Holway and Ward, 1963). Rochow (1969) found that individual Caltha from areas of intermediate snow cover had the highest growth rates and produced the most biomass. He concluded that intermediate positions along gradients of temperature, soil moisture, and growing season length were most favorable for that species. In our study area, the last area to become snow free showed highest Caltha productivity. This apparent discrepancy may be due to either differences in the range of snow cover conditions examined (increasing length of snow cover must eventually lead to zero productivity), or the fact that Rochow terminated his study prior to attainment of peak biomass.

Dominance-diversity curves (Figure 2) indicate that simple dominance relationships among the plant species determine the apportionment of resources in snow zone 1. The nearly linear form of the curve suggests that the underlying species-dominance distribution approximates a geometric series, i.e., a distribution in which (ideally) the most successful species preempts a fraction $k$ of the available resources, the next a fraction $k$ of the remainder, and so on (May, 1975). Such distributions are considered typical of harsh environments (Whittaker, 1975: 93). Geometric series distributions are generally found in plant communities with few species and/or which have a single factor dominating species relationships. An obvious factor potentially limiting to species in snow zone 1 is soil moisture.

The dominance-diversity curve of snow zone 4 suggests that the underlying speciesdominance distribution approximates a lognormal distribution. The lognormal distribution results whenever a large number of moreor-less independent factors influence the dominance relationships among species. Because the presence of the lognormal distribution is a predictable outcome whenever the number of species in a sample becomes large (May, 1975), caution is necessary regarding judgements as to the causal mechanisms underlying the pattern observed in curve 4 , Figure 2. It seems likely, however, that the relative success of the many species contributing minor amounts to the aboveground productivity within snow zone 4 is due to the influences of variation in snowpack (as it affects the length of the growing season), summer weather conditions, and/or animal disturbance, as well as to the soil moisture availability probably predominating in snow zone 1 . The same statement could be made regarding snow zones 3 and 2 relative to snow zone 1 , with varying degrees of influence due to soil moisture. Thus, the variation in dominancediversity relationships between the snow zones suggests that the effect of snow cover in controlling the length of the growing season may be less important than its influence on moisture availability in determining the overall structure of this subalpine community. Growing season length and moisture availability are in all likelihood the major factors responsible for the paucity of important species common to early and late opening areas (Table 3 ). This agrees with Webber's (1974) conclusions concerning controlling site factors in six alpine vegetation types on Niwot Ridge.

The influence of domestic sheep in determining the structure of the vegetation within the snow zones is unknown. Studies of food preferences on subalpine rangeland suggest sheep generally prefer forbs (see review by Thilenius, 1975). Strasia et al. (1970) found that sheep selectively ate species of both forbs and graminoids on an alpine range. Such dif- 
ferential herbivory could undoubtedly lead to modification of both the composition and the pattern of productivity (dominance) in a subalpine plant community, given sufficient intensity or duration.

Obviously, more work is needed to elucidate the relationships between the structure and productivity of these high subalpine meadow-krummholz communities. To regard these areas as simple extensions of alpine communities, or as counterparts to more temperate communities may be misleading, since the physical and biotic environments encountered in subalpine communities may make them more complex than either alpine tundra or montane meadow.

\section{ACKNOWLEDGMENTS}

It is a pleasure to acknowledge the technical assistance and perseverance of Sherry $L$. Andersen. Her efforts in North Pole Basin made this study possible. The study was supported in part by grants GB4014X, GB32494, and DEB 75-13996 from the National Science Foundation. James A. MacMahon, Martyn

\section{REFERENCES CITED}

Andersen, D. C., Armitage, K. B., and Hoffmann, R. S., 1976: Socioecology of marmots: female reproductive strategies. Ecology, 57: 552-560.

Barry, R. G. and Ives, J. D., 1974: Introduction. In Ives, J. D. and Barry, R. G. (eds.), Arctic and Alpine Environments. London: Methuen, 1-13.

Billings, W. D. and Bliss, L. C., 1959: An alpine snowbank environment and its effects on vegetation, plant development and productivity. Ecology, 40: 388-397.

Bliss, L. C., 1969: Alpine community pattern in relation to environmental parameters. In Greenridge, K. N. H. (ed.), Essays in Plant Geography and Ecology. Halifax: Nova Scotia Museum, 167-184.

Bradbury, I. K. and Hofstra, G., 1976: Vegetation death and its importance in primary production measurements. Ecology, 57: 209-211.

Canaday, B. B. and Fonda, R. W., 1974: The influence of subalpine snowbanks on vegetation pattern, production, and phenology. Bulletin of the Torrey Botanical Club, 101: 340-350.

Curtis, J. T. and McIntosh, R. P., 1951: An upland forest continuum in the prairie-forest border region of Wisconsin. Ecology, 32: 476-496.

Holway, J. G. and Ward, R. T., 1963: Snow and meltwater effects in an area of Colorado alpine. American Midland Naturalist, 69: 189-197.

Johns, D. W., 1978: Personal communication. Department of Systematics and Ecology, University of Kansas, Lawrence.

Johns, D. W. and Armitage, K. B., 1979: Behavioral ecology of alpine yellow-bellied marmots. Behavioral Ecology and Sociobiology, 5:
M. Caldwell, and an anonymous reviewer provided valuable comments on the manuscript. The senior author wishes especially to acknowledge the support received from Dr. MacMahon during the final stages of analysis and writing.

\section{3-157.}

Kuramoto, R. T. and Bliss, L. C., 1970: Ecology of subalpine meadows in the Olympic Mountains, Washington. Ecological Monographs, 40: $317-347$

Langenheim, J. H., 1962: Vegetation and environmental patterns in the Crested Butte area, Gunnison County, Colorado. Ecological Monographs, 32: 249-285.

May, R. M., 1975: Patterns of species abundance and diversity. In Cody, M. L. and Diamond, J. M. (eds.), Ecology and Evolution of Communities. Cambridge, Mass.: Belknap Press, 81-120.

McIntosh, R. P., 1958: Plant communities. Science, 128: 115-120.

Rochow, T. F., 1969: Growth, caloric content, and sugars in Caltha leptosepala in relation to alpine snowmelt. Bulletin of the Torrey Botanical Club, 96: 689-698.

Sokal, R. R. and Sneath, P. H. A., 1963: Principles of Numerical Taxonomy. San Francisco: Freeman. $359 \mathrm{pp}$.

Strasia, C. A., Thorn, M., Rice, R. W., and Smith, D. R., 1970: Grazing habits, diet, and performance of sheep on alpine ranges. Journal of Range Management, 23: 201-208.

Thilenius, J. F., 1975: Alpine range management in the western United States-principles, practices, and problems: the status of our knowledge. U. S. Department of Agriculture, Forest Service Research Paper, RM-157. 32 pp.

Thilenius, J. F., Smith, D. R., and Brown, G. R., 1974: Effect of 2,4-D on composition and production of an alpine plant community in Wyoming. Journal of Range Management, 27: 140142. 
Webber, P. J., 1974: Tundra primary productivity. In Ives, J. D. and Barry, R. G. (eds.), Arctic and Alpine Environments. London: Methuen, 445-473.

Webber, P. J. and May, D. E., 1977: The magnitude and distribution of belowground plant structures in the alpine tundra of Niwot Ridge, Colorado. Arctic and Alpine Research, 9: 157 . 174.

Whittaker, R. H., 1965: Dominance and diversity in land plant communities. Science, 147: 250 260 .
1975: Communities and Ecosystems, 2nd ed. New York: Macmillan. 388 pp.

Wiegert, R. G., 1962: The selection of an optimum quadrat size for sampling the standing crop of grasses and forbs. Ecology, 43: 125-129. Wielgolaski, F. E., 1974: Phenological studies in tundra. In Lieth, H. (ed.), Phenology and Seasonality Modeling. New York: Springer-Verlag, 209-214. 